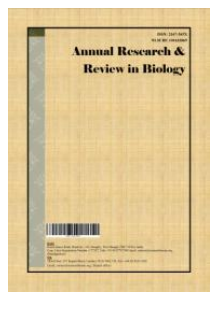

\title{
Influence of the Habitat on Marine Macroalgae Toxicity
}

\author{
Sergio Alvarez-Hernández ${ }^{1^{*}}$, Cruz Lozano-Ramírez ${ }^{1}$ \\ and Mónica Rodríguez-Palacio ${ }^{1}$
}

${ }^{1}$ Laboratorio de Ficología Aplicada, Departamento de Hidrobiología, Universidad Autónoma Metropolitana - Iztapalapa, A.P. 55-535, C.P. 09340, Ciudad de Ciudad de México, México.

Authors' contributions

This work was carried out in collaboration among all authors. Authors SAH, CLR and MRP designed the study, wrote the protocol and wrote the first draft of the manuscript. Author SAH managed the analyses of the study. Authors SAH, CLR and MRP managed the literature searches, read and approved the final manuscript.

Article Information

DOI: $10.9734 / A R R B / 2019 /$ v33i130113

(1) Dr. Md. Aminur Rahman, Professor, World Fisheries University Pilot Programme, Pukyong National University (PKNU),

South Korea.

Reviewers:

(1) Abou-Hamdan Hussein, Lebanese University, Lebanon.

(2) Leonel Pereira, University of Coimbra, Portugal.

(3) Adegbite Adesola Victor, Ladoke Akintola University of Technology, Nigeria. Complete Peer review History: http://www.sdiarticle3.com/review-history/50349

Original Research Article

Received 01 July 2019

Accepted 03 September 2019

Published 17 September 2019

\section{ABSTRACT}

Macroalgae synthesize molecules that may be toxic to other organisms. These molecules are synthesized as a defense strategy against herbivores. It has been proven that the synthesis process is directed by several physiological, chemical and even spatial-temporal variables. The purpose of this study was to determine whether the complexity of the habitat influences on the expression of marine macroalgae toxicity. Algae of 31 species (39 samples) were collected in localities with different habitat morphology: a coral reef in the Mexican Caribbean, three myxohaline localities in the Yucatán peninsula and six rocky intertidal localities, four of these in the Mexican Pacific and two in the Gulf of Mexico. Results identified 19 strongly toxic species from the reef, followed by algae collected in the rocky intertidal area, and the least number of toxic species in the myxohaline environments. The results support the hypothesis established by several researchers worldwide regarding the complexity of coral reefs, which promotes the synthesis of toxic substances as a defense against herbivores. These substances have been employed as molecules that are useful in the fight against diseases or as synthesis matrices of other compounds with pharmacological potential. 
Keywords: Toxicity; ichthyotoxicity; macroalgae; habitat; Mexico.

\section{INTRODUCTION}

A great diversity of marine organisms produce toxins as part of their metabolism. Among these are Cyanobacteria and dinoflagellates (Miozoa, Dinophyseae) [1,2,3], sponges (Porifera) [4,5], ascidians (Chordata, Ascidiacea) [6,7,8] and ahermatypic corals (Cnidaria, Anthozoa) $[9,10,11]$. Secondary metabolites are important in the regulation of a variety of defense mechanisms, and many are considered more potent a few toxic macromolecules [12,13,14]. Macroalgae also produce a series of secondary metabolites that are intermediaries of ecological responses, as occurs in the case of chemical defense against herbivory $[15,16,17,18,19]$, antifouling $[20,21]$ and those responsible for allelopathic responses $[22,23,24]$.

Macroalgae produce a great number of secondary metabolites including terpenes, aromatic compounds, acetogenins, polyphenols and fluorotannins, substances derived from amino acids and various alkaloids $[25,26,27]$ that are ecologically useful to algae. Substances synthesized by species of the Dictyotaceae (Ochrophyta, Phaeophyceae), like the Dictyoles (dictyol B, dictyol acetate A, B, H and pachydictyol), act against herbivores and are also used as a defense against epiphytes and epibionts that invade algal surfaces $[28,29,30,31]$. Many members of the Division Rhodophyta synthesize biologically active metabolites that vary from simple brominated aromatic acetones and brominated phenols to mono, diterpene and sesquiterpene complexes $[32,33,34]$. Algae of the Division Chlorophyta mainly synthesize di- and sesquiterpenes that have a variety of biological activities including antiherbivory, bactericidal, antifungal and spermicidal, among others $[33,34,35,36]$.

Many authors had pointed out that marine habitat complexity can influence ecological and physiological relations between organisms as synthesis of diverse molecules, among others $[37,38,39,40,41,42]$.

Mexico has more than $10,000 \mathrm{~km}$ of coastline that, as a result of its geological diversity, provide diverse habitats that marine organisms use to establish complex ecological relationships. It is well known that herbivorous fish in coral reefs exert a great pressure on algae, favoring an increase in algal diversity, though with a lower biomass than that in temperate zones or in rocky intertidal areas, where herbivory pressure is mainly due to invertebrates. However, this pressure causes the algae that survive and prosper to be chemically protected $[43,44]$.

In Mexico, studies on marine macroalgae toxicity are scarce, despite the high species diversity of these organisms along its coasts $[45,46]$. It is thus important to carry out an inventory of the algal species that grow in Mexico and its molecules, that may potentially be useful in medicine, chemistry and biochemistry. The purpose of this study was to detect the presence of toxicity in marine algae of the Mexican coasts and relate the presence of this biological activity to the habitat where these organisms develop.

\section{MATERIALS AND METHODS}

\subsection{Collection of Algal Material}

Algae were collected manually along the intertidal fringe of the described localities (Fig. 1). The algal material was separated from the rock at its base with a spatula, rinsed with sea water, separated by genus, frozen with solid $\mathrm{CO}_{2}$, and transported to the laboratory for analysis. Ten localities were visited, four in the Yucatán peninsula, four in the Mexican Pacific and two in the Gulf of Mexico. Only one locality was visited in the Mexican Caribbean, the Puerto Morelos reef $\left(20^{\circ} 50^{\prime} 08^{\prime \prime} \mathrm{N}\right.$ and $\left.86^{\circ} 55^{\prime} 04^{\prime \prime} \mathrm{W}\right)$ in the state of Quintana Roo, located north of Playa del Carmen, a Caribbean reef complex. The localities of the Gulf of Mexico are wetlands formed by the locally-called "aguadas", which are upwelling's of sub-surface water or rivers that flow into the sea. These include Dzilam de Bravo $\left(21^{\circ} 23^{\prime} 43^{\prime \prime} \mathrm{N}\right.$ and $\left.88^{\circ} 52^{\prime} 55^{\prime \prime} \mathrm{W}\right)$, Chelem ( $21^{\circ}$ $14^{\prime} 35^{\prime \prime} \mathrm{N}$ and $\left.89^{\circ} 50^{\prime} 34^{\prime \prime} \mathrm{W}\right)$ and Celestún $\left(20^{\circ}\right.$ $51^{\prime} 33^{\prime \prime} \mathrm{N}$ and $90^{\circ} 22^{\prime} 51^{\prime \prime} \mathrm{W}$ ) in the state of Yucatán. Champotón (19' 19' 14' $\mathrm{N}$ and 90 44' $53^{\prime \prime} \mathrm{W}$ ), in the state of Campeche, is an artificial breakwater located at the mouth of the river of the same name. The localities in the state of Veracruz were the breakwater of Alvarado harbour ( $18^{\circ} 47^{\prime} 24^{\prime \prime} \mathrm{N}$ and $\left.95^{\circ} 44^{\prime} 34^{\prime \prime} \mathrm{W}\right)$, to the south of the lagoon inlet, that provides a fairly complex habitat for algal populations to settle. Boca del Río (19 9' $53^{\prime \prime} \mathrm{N}$ and $96^{\circ} 6^{\prime} 16^{\prime \prime} \mathrm{W}$ ) is a shallow open beach with artificial breakwaters on which algae grow. Costa de Oro $\left(19^{\circ} 9^{\prime} 21^{\prime \prime} \mathrm{N}\right.$ and $96^{\circ} 5^{\prime} 45^{\prime \prime} \mathrm{W}$ ) is a beach with many submerged boulders, ideal for the settlement of 
large and diverse algal populations, located in an area of great hotel and commercial growth, in the municipality of Boca del Río. Along the Mexican Pacific, in the state of Michoacán, are Punta San Telmo $\left(18^{\circ} 37^{\prime} 26^{\prime \prime} \mathrm{N}\right.$ and $\left.103^{\circ} 41^{\prime} 7^{\prime \prime} \mathrm{W}\right)$ to the north of the town of the same name, a rocky shore with a steep slope and difficult access, and Faro de Bucerías (18 $20^{\circ} 40^{\prime \prime} \mathrm{N}$ and $103^{\circ} 30^{\prime}$ $\left.40^{\prime \prime} \mathrm{W}\right)$, a rocky outcrop where the morphology of the rocky coves generates complex habitats. In the state of Guerrero, Puerto Vicente Guerrero $\left(17^{\circ} 16^{\prime} 11^{\prime \prime} \mathrm{N}\right.$ and $101^{\circ} 3^{\prime}$ 9''W), also called Puerto Escondido or Playa Escondida, was formed by two gigantic artificial breakwaters that provide a quite complex habitat, and La Barrita $\left(17^{\circ} 24^{\prime} 32^{\prime \prime} \mathrm{N}\right.$ and $\left.101^{\circ} 10^{\prime} 52^{\prime \prime} \mathrm{W}\right)$, in the municipality of Petatlán, provides a natural rocky area of medium extension where algal populations are seen to grow.

\subsection{Extract Preparation}

The samples were unfrozen at room temperature in order to obtain the extracts. One part of each sample was preserved in glycerinated formalin for later identification of the species and preparation of reference specimens for the herbarium of the Applied Phycology Laboratory. The remaining material was washed under running water and cleaned under a microscope to free it of epiphytes and other impurities that could affect the results.

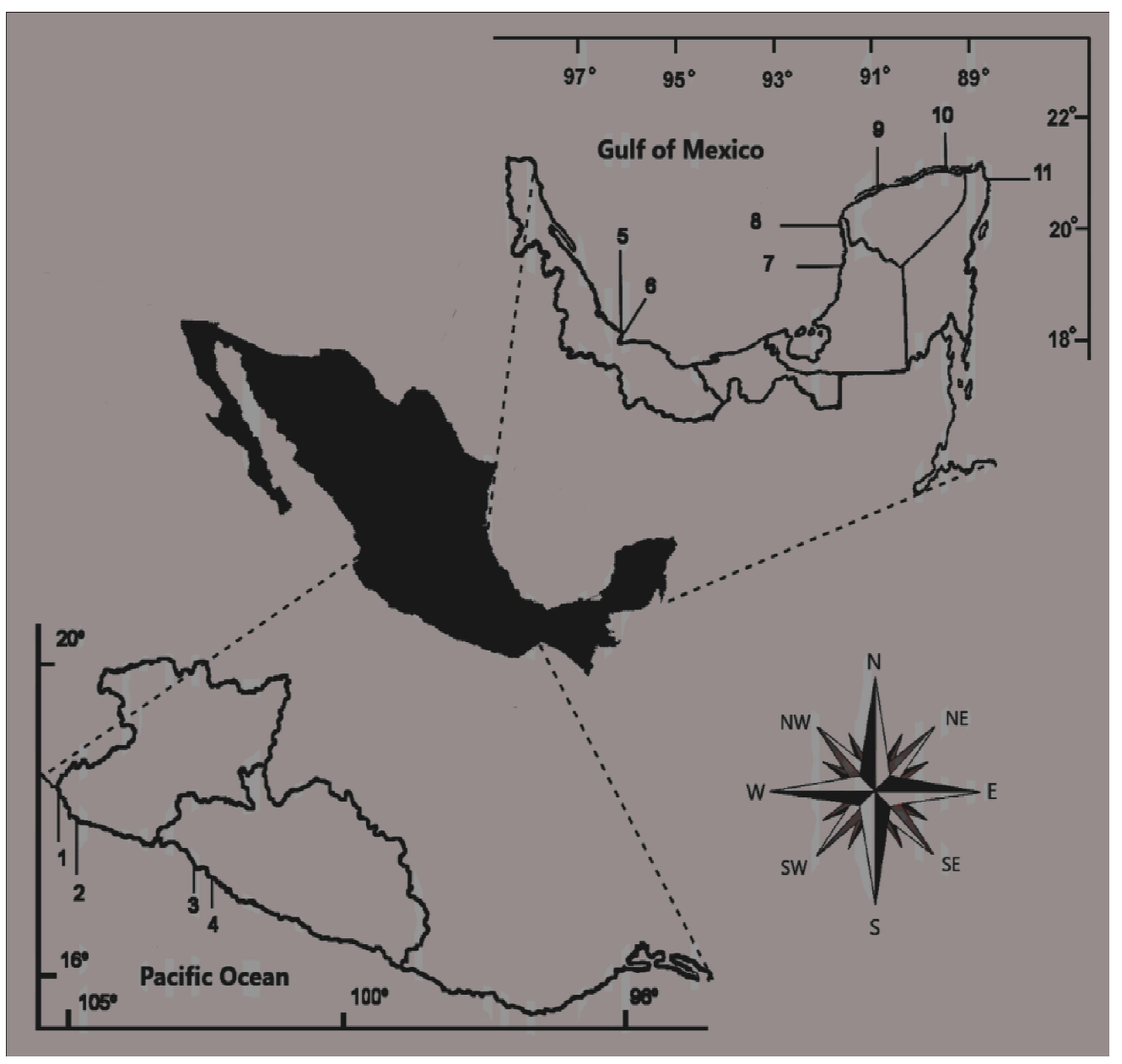

Fig. 1. Localities of algal material collection: 1. Punta San Telmo, 2. Faro de Bucerías

(Michoacán); 3. La Barrita, 4. Puerto Vicente Guerrero (Guerrero) Pacific Ocean Coast. 5. Boca del Río, 6. Costa de Oro (Veracruz); 7. Champotón, 8. Celestún (Campeche); 9. Chelem, 10. Dzilam (Yucatán) Gulf of Mexico Coast. 11. Puerto Morelos (Quintana Roo) Mexican Caribbean Coast 
Algal extracts were prepared mixing $50 \mathrm{~g}$ of alga and $150 \mathrm{ml}$ of solvent (alcohol, acetone or distilled water). The mixture was centrifuged at $3,400 \mathrm{rpm}$ for 20 minutes at $6^{\circ} \mathrm{C}$. The supernatant was dried by roto-evaporation and the crystals that were obtained were resuspended using 0.9 ups saline solution used for the extraction $[47,48,49]$.

\subsection{Bioassays}

The goldfish Carasius auratus auratus (Linnaeus, 1758) was used as a test animal in order to detect extract toxicity. Toxicity tests were carried out in triplicate, in $250 \mathrm{ml}$ crystallizers containing $200 \mathrm{ml}$ of aquarium water and $1 \mathrm{ml}$ of the extract to be tested. Controls were prepared by adding 1 $\mathrm{ml}$ of the 0.9 ups saline solution. Solvent was evaporated before experimental test, in order to ensure that the results of possible toxicity were solely responsibility of unknown substances $[49,50]$. The extracts were classified based on the behavior of the organisms as Toxic ( $T$ ) when the fish died during the test period (2 hs), Moderately Toxic (MT) when the fish did not die but presented behavioral changes such as fast or slow movements, loss of balance and in some cases paralysis, and recuperated after a time, and Non Toxic $(-)$ when the fish did not react and their behavior was similar to that of the controls. The surviving fish were placed in clean water for a period of $24 \mathrm{hs}$.

\subsection{Statistical Analysis}

Correlation between hábitat complexity and toxicity potency was calculated, using the classification of Carvalho. Coral Reef habitat was defined as the more complex, while coastal lagoons were defined as less complex habitats [37]. PAST software, ver. 3.2, was used for check the compliance of normality assumptions, if data did not reach normality, a Spearman correlation calculation was performed [51].

\section{RESULTS}

Bioassay results are presented in Table 1. Algae of 31 species were collected and included six of Chlorophyta, seven of Phaeophyceae and 18 of Rhodophyta (39 samples). A species was considered highly toxic when toxicity was detected in at least one of its extracts. This occurred in six species of Chlorophyta, four of Phaeophyceae and nine of Rhodophyta (total 19,
$62 \%$ ). Only two species of Rhodophyta were considered moderately toxic (total 2, 6.4\%), when moderate toxicity was detected in all their extracts. Three species of Phaeophyceae and seven of Rhodophyta presented no toxicity (total $10,32 \%)$. The most toxic species were Caulerpa cupressoides, C. racemosa, C. paspaloides, Chaetomorpha antennina and Penicillus capitatus (Chlorophyta), Dictyopteris delicatula, Padina gymnospora (formerly Padina vickersiae) and Stypopodium zonale (Phaeophyceae), and Ceramium nitens, Gracilaria tikvahiae, Laurencia obtusa and Liagora ceranoides (Rhodophyta). Of special note is the potent activity of Chondriopsis dasyphylla f. pyrifera (Rhodophyta), of which the three extracts were toxic. With respect to the localities where algae were collected, the 12 species with the greatest toxicity were collected mostly in three localities, the Puerto Morelos reef in the Caribbean, Costa de Oro in the Gulf of Mexico and Faro de Bucerías in the Mexican Pacific. A change in toxicity level was detected in Caulerpa cupressoides, Acantophora spicifera, Gracilaria cervicornis, Hypnea musciformis and Laurencia obtusa with respect to the date and locality of collection (Table 1). Regarding the solvent, 24 of the extracts obtained using acetone had toxic activity, 20 toxic extracts were obtained using ethanol, and only the toxic extract, of Chondriopsis dasyphylla f. pyrifera, was obtained using water. Correlation analysis showed a direct relation between habitat complexity and toxicity potency among algae from Chlorophyta, $r s=0.84, p<0.05$, among Rhodophyta species also was observed a direct relation between both parameters $r s=0.87, p<$ 0.05 . Algae from Phaophyceae class did not showed any relation due to the small sample size $(n=4)$.

\section{DISCUSSION}

Variations in the potency of macroalgal toxic activity have been related to ecological actions for protection against herbivory, as was conclusively proven by $[29,52,35]$ observed that the complexity of habitats in reef areas increased the ecological process of herbivory, leading macroalgae to develop protection mechanisms such as the formation of hard structures (calcification), or chemical protection through the production of toxic secondary metabolites, or both. In contrast, in algae that grow in other types of habitats, such as rocky shores or coastal lagoons that receive sea water, the development of strong chemical defenses is not clear [53]. 
Alvarez-Hernández et al.; ARRB, 33(1): 1-9, 2019; Article no.ARRB.50349

Table 1. Localities: 1. Yucatán, 2. Quintana roo, 3. Michoacán, 4. Veracruz, 5. Guerrero, 6. Campeche. Toxicity: - nontoxic extract, MT Moderately toxic extracts, T toxic extract

\begin{tabular}{|c|c|c|c|c|c|}
\hline Division/Species chlorophyta & Locality & Date of collection & Aqueous & Ethanolic & Acetonic \\
\hline Anadyomene stellata (Wulfen) C.Agardh & ${ }^{1}$ Dzilam & Apr 99 & - & MT & $\mathrm{T}$ \\
\hline Caulerpa cupressoides (West) C. Agardh & ${ }^{2}$ Pto. Morelos & Jun 99 & - & - & - \\
\hline Caulerpa cupressoides (West) C. Agardh & ${ }^{2}$ Pto. Morelos & Feb 99 & - & $\mathrm{T}$ & $\mathrm{T}$ \\
\hline Caulerpa cupressoides (West) C. Agardh & ${ }^{2}$ Pto. Morelos & Feb 99 & - & MT & MT \\
\hline Caulerpa paspaloides (Bory) Greville & ${ }^{1}$ Chelem & May 97 & - & MT & $\mathrm{T}$ \\
\hline Caulerpa racemosa (Forssk.) J. Agardh & ${ }^{3}$ Faro de Bucerías & Apr 95 & - & - & $\mathrm{T}$ \\
\hline Chaetomorpha antennina (Bory) Kütz. & ${ }^{3}$ Faro de Bucerías & Apr 95 & - & - & $\mathrm{T}$ \\
\hline Penicillus capitatus J.V. Lamour. & ${ }^{2}$ Pto. Morelos & Jun 97 & - & $\mathrm{T}$ & $\mathrm{T}$ \\
\hline \multicolumn{6}{|l|}{ Ochrophyta, Phaeophyceae } \\
\hline Dictyopteris delicatula J.V. Lamour & ${ }^{2}$ Pto. Morelos & Feb-99 & - & $\mathrm{T}$ & $\mathrm{T}$ \\
\hline Dictyota implexa (as D. linearis C. Agardh, Greville) & ${ }^{1}$ Celestún & May 97 & - & - & - \\
\hline Dictyota bartayresiana Lamour. & ${ }^{3}$ Pta. San Telmo & Apr 95 & - & - & - \\
\hline Lobophora variegata (J.V. Lamour.) Womersley & ${ }^{2}$ Pto. Morelos & Nov 96 & - & - & - \\
\hline Padina gymnospora (as $P$. vickersiae Hoyt.) & ${ }^{3}$ Faro de Bucerías & Apr 95 & - & - & $\mathrm{T}$ \\
\hline Sargassum liebmannii J. Agardh. & ${ }^{3}$ Faro de Bucerías & Apr 95 & - & MT & $\mathrm{T}$ \\
\hline Stypopodium zonale (J.V. Lamour.) Papenf. & ${ }^{2}$ Pto. Morelos & Feb 99 & - & $\mathrm{T}$ & $\mathrm{T}$ \\
\hline \multicolumn{6}{|l|}{ Rhodophyta } \\
\hline Acanthophora spicifera (Vahl) Børgesen & ${ }^{4}$ Costa de Oro & Nov 94 & - & - & - \\
\hline Acanthophora spicifera (Vahl) Børgesen & ${ }^{2}$ Pto. Morelos & Feb 99 & - & MT & $\mathrm{T}$ \\
\hline Acanthophora spicifera (Vahl) Børgesen & ${ }^{1}$ Dzilam & Apr 99 & - & MT & MT \\
\hline Amphiroa beauvoisii (as A. mexicana W.R. Taylor) & ${ }^{3}$ Faro de Bucerías & Apr 95 & - & $\mathrm{T}$ & MT \\
\hline Centroceras clavulatum (C. Agardh) Mont. & ${ }^{5}$ La Barrita & Apr 95 & - & $\mathrm{T}$ & MT \\
\hline Ceramium nitens (C. Agardh) J. Agardh. & ${ }^{2}$ Pto. Morelos & Feb 99 & - & $\mathrm{T}$ & $\mathrm{T}$ \\
\hline Chondria littoralis Harvey & ${ }^{4}$ Costa de Oro & Nov 94 & - & - & - \\
\hline Chondriopsis dasyphylla f. pyrifera J. Agardh & ${ }^{2}$ Pto. Morelos & Feb 99 & $\mathrm{~T}$ & $\mathrm{~T}$ & $\mathrm{~T}$ \\
\hline Crassiphycus caudatus (as Gracilaria caudata J. Agardh) & ${ }^{4}$ Costa de Oro & Nov 94 & - & - & - \\
\hline Dermonema virens (C. Agardh) Pedroche \& Ávila Ortiz & ${ }^{5}$ Pto. Vicente Gro & Ago 97 & - & - & - \\
\hline Digenea simplex (Wulfen) C. Agardh & ${ }^{2}$ Pto. Morelos & Jun 97 & - & - & - \\
\hline Gracilaria cervicornis (Turner) J. Agardh & ${ }^{4}$ Boca del Río & Nov 94 & - & - & MT \\
\hline Gracilaria cervicornis (Turner) J. Agardh & ${ }^{4}$ Costa de Oro & Nov 94 & - & MT & $\mathrm{T}$ \\
\hline Gracilaria tikvahiae McLachlan & ${ }^{4}$ Costa de Oro & Nov 94 & - & - & $\mathrm{T}$ \\
\hline Grateloupia filicina (C. Agardh) Lamour. & ${ }^{4}$ Boca del Río & Nov 94 & - & - & - \\
\hline Grateloupia filicina (J.V. Lamour.) C. Agardh & ${ }^{4}$ Escollera-Alvarado & Nov 94 & - & - & - \\
\hline Hypnea musciformis (Wulfen) J.V. Lamour. & $\begin{array}{l}{ }^{4} \text { Boca del Río } \\
\text { Bun }\end{array}$ & Nov 94 & - & - & - \\
\hline Hypnea musciformis (Wulfen) J.V. Lamour. & ${ }^{4}$ Costa de Oro & Nov 94 & - & MT & MT \\
\hline Hypnea spinella (Wulfen) J.V. Lamour. & ${ }^{5}$ La Barrita & Apr 95 & - & MT & MT \\
\hline Laurencia obtusa (Huds.) J.V. Lamour. & ${ }^{2}$ Pto. Morelos & Jun 97 & - & $\mathrm{T}$ & $\mathrm{T}$ \\
\hline Laurencia obtusa (Huds.) J.V. Lamour. & ${ }^{6}$ Champotón & Jun 97 & - & MT & MT \\
\hline Liagora ceranoides J.V. Lamour. & ${ }^{2}$ Pto. Morelos & Feb 99 & - & $\mathrm{T}$ & - \\
\hline Tayloriella dictyurus (J. Agardh) Kylin & ${ }^{3}$ Pta. San Telmo & Apr 95 & - & - & - \\
\hline Yuzurua poiteaui var. gemmifera (Harvey) M.J.Wynne & ${ }^{6}$ Champotón & Jul 97 & - & - & - \\
\hline
\end{tabular}


The results obtained in the present study coincide totally with these findings, since in all cases the algae with potent toxicity in at least one of their extracts were collected in the reef system of the Mexican Caribbean, nine of 10 tested species caused test animals to die when exposed to at least one of their extracts, and only one species was not toxic and revealed with statistical analysis results.

The algae collected in freshwater areas with marine influence (myxohaline environments) were recorded with the lowest toxicity in this study (Dzilam, Celestún and Chelém). The algae collected in rocky intertidal localities presented an intermediate toxicity spectrum, with an increase in the number of moderately toxic species. Of note is Faro de Bucerías, in Michoacán, where the great number of tidal pools and spaces carved in the rock by erosion provides a degree of morphological complexity, and all algae were toxic. In contrast, a smaller number of toxic algae and a decrease in toxicity potency were observed in the macroalgae collected in nearby localities like La Barrita and Puerto Vicente Guerrero, which are typical simple rocky areas (Table 1). [52] stated that reefs are complex habitats due to the great number of areas that provide protection, facilitate escape from predators, and sustain a high algal diversity. The coral reef at Puerto Morelos is the second longest in the world, and it has the characteristics that are required for algal species to develop potent chemical defenses in response to the strong herbivory pressure they are subjected to, as was recorded by the results obtained in this study.

The cases where algae presented a moderate toxicity in one extract and a high toxicity in another (Caulerpa cupresoides, C. paspaloides, Sargassum liebmanii, Acantophora spicifera, Amphiroa mexicana, Centroceras clavulatum and Gracilaria cervicornis) may be explained considering that the solvent was not completely effective in extracting the toxic molecule and dissolved only a low concentration of it, resulting in a medium toxicity. This occurs frequently as the solvents that are used have a similar polarity. We tried test two solvents of similar polarity in order to probe this statement observed in the literature, but we used also a good extractor of interest molecules as the acetone.

It was also observed that some species, when collected at different times, decreased or lost their toxicity (Table 1). This occurred in samples of Caulerpa cupressoides collected in the same locality, with that of June presenting no toxicity and those of other dates being toxic. The presence/absence of toxicity has been well studied in this family (Caulerpaceae), and has been associated with algal age, with the younger plants being more toxic than the older and longer plants $[54,43,55]$.

Several species presented a varied pattern related to the locality where they were collected. Acantophora spicifera and Laurencia obtusa had a variable level of toxicity, with the sample collected in the Puerto Morelos reef being more toxic than the sample collected in a myxohaline environment. In this case, it is clear that this is the result of herbivory pressure, which makes one species toxic and not another, notwithstanding that the sampling dates and localities were close $[54,55]$.

In the case of Gracilaria cervicornis and Hypnea musciformis, these species were collected in Veracruz on the same day from habitats with a similar complexity. Variations in toxicity on a geographical scale have been studied for algae of the Phaeophyceae class, with those that develop in tropical and subtropical areas having a greater toxicity than those of temperate areas. However, this phenomenon is not yet quite understood. It is possible that it is related to physiological variables of the algal populations that grow in these areas or to a decrease in nutrients that restricts the production of toxic metabolites [56].

The high number of species that are toxic is an indirect indication of the ecological relationships that are present in the different habitats where macroalgae grow. Toxic molecules may be directly used in the struggle against diseases such as HIV, various viruses and carcinogenic tumors, or as base molecules that, after changing through chemical synthesis, may enhance their spectrum and force of action against these ailments, as we can see in the review of [57]. In Mexico, greater research efforts need to focus on identifying the number and type of toxic molecules present in algae that may be used in medicine, clinical studies, chemistry and biochemistry, among others.

\section{CONCLUSIONS}

It was detected a gradient of toxicity related with the complexity of the habitat, the more toxic macroalgae extracts were founded in reef 
localities, followed by rocky intertidal ambient and the last were at myxohaline environments. Also was observed the presence/absence of toxicity due to the locality of collection and to the climate date, previously observed in the world. Large amount of toxic species can be used in pharmacological research for potential application against HIV, various viruses and carcinogenic tumors or as molds molecules.

\section{COMPETING INTERESTS}

Authors have declared that no competing interests exist.

\section{REFERENCES}

1. Singh S, Kate BN, Banerjee UC. Bioactive compounds from cyanobacteria and microalgae: An overview. Critical Reviews in Biotechnology. 2005;25:73-95.

2. Russell JSO, Stüken A, Murray SA, Jakobsen KS. Evolution and distribution of saxitoxin biosynthesis in dinoflagellates. Marine Drugs. 2013;11(8):2814-2828.

3. Dittmann E, Fewer DP, Neilan BA. Cyanobacterial toxins: Biosynthetic routes and evolutionary roots. FEMS Microbiology Review. 2013;37:23-43.

4. Tang LT, Williamson RT, Gerwick WH. cis, cis- and trans, trans-Ceratospongamide, new bioactive cyclic heptapeptides from the Indonesian red alga Ceratodictyon spongiosum and symbiotic sponge Sigmadocia symbiotica. Journal of Organic Chemistry. 2000;65:419-425.

5. Puyana M, Pawlik J, Blum J, Fenical W. Metabolite variability in Caribbean sponges of the genus Aplysina. Revista Brasileira de Farmacognosia-Brazilian Journal of Pharmacognosy. 2015;25:592-599.

6. Teo SLM, Ryland JS. Toxicity and palatability of some British ascidians. Marine Biology. 1994;120(2):297-303.

7. Teruya $\mathrm{T}$, Suenaga $\mathrm{K}$, Maruyama $\mathrm{S}$, Kurotaki M, Kigoshi $H$. Biselides A-E: Novel polyketides from the Okinawan ascidian Didemnidae sp. Tetrahedron. 2005;61(27):6561-6567.

8. Watters DJ. Ascidian toxins with potential for drug development. Marine Drugs. 2018;16(5):162.

9. La Barre SC, Coll JC, Sanmarco PW. Competitive strategies of soft corals (Coelenterata: Octocorallia). III. Spacing and aggressive interactions between alcyonaceans. Marine Ecology Progress Series. 1986;128:147-156.

10. Rezanka T, Dembitsky VM. $\gamma$-Lactones from the soft corals Sarcophyton trocheliophorum and Lithophyton arboretum. Tetrahedron. 2001;57(41): 8743-8749.

11. Ben-Ari H, Paz M, Sher D. The chemical armament of reef-building corals: inter- and intra-specific variation and the identification of an unusual actinoporin in Stylophora pistilata. Nature Scientific Reports. 2018;8: 251.

12. Cavalier-Smith T. Origins of secondary metabolism. In: Derek J. Chadwick \& Julie Whelan (Eds) Ciba Foundation Symposium 171 - Secondary Metabolites: Their Function and Evolution. 1992;64-87.

13. Sammarco PW, Coll JC. Secondary metabolites - or primary? Re-examination of a concept through a marine example. Proceedings of the $8^{\text {th }}$ International Coral Reef Symposium. 1997;2:1245-1250.

14. Giordano D, Coppola D, Russo R, Denaro R, Giuliano L, Lauro FM, di Prisco G, Cinzia V. Marine microbial secondary metabolites: Pathways, evolution and physiological roles. In: Poole, R. K. (Ed) Advances in Microbial Physiology. Elsevier. 2015;66:357-428.

15. Amsler CD. Induced defenses in macroalgae: The herbivore makes a difference. Journal of Phycology. 2001;37: 353-356.

16. Paul VJ, van Alstyne KL. Activation of chemical defenses in the tropical green algae Halimeda spp. Journal of Experimental Marine Biology and Ecology. 1992;160:191-203.

17. Cronin G, Hay ME. Induction of seaweed chemical defenses by amphipod grazing. Ecology. 1996;77(8):2287-2301.

18. Sotka EE, Wares JP, Hay ME. Geographic and genetic variation in feeding preference for chemically defended seaweeds. Evolution. 2003;57(10):2262-2276.

19. Pal A, Kamthania MC, Kumar A. Bioactive compounds and properties of seaweeds A review. Open Access Library Journal. 2014;1:e752.

20. Bhadury $P$, Wright PC. Exploitation of marine algae: Biogenic compounds for potential antifouling applications. Planta. 2004;219:561-578.

21. Maréchal J-P, Culioli G, Hellio C, ThomasGuyon H, Callow ME, Clare AS, OrtaloMagné A. Seasonal variation in antifouling 
activity of crude extracts of the brown alga Bifurcaria bifurcata (Cystoseiraceae) against cyprids of Balanus amphitrite and the marine bacteria Cobetia marina and Pseudoalteromonas haloplanktis. Journal of Experimental Marine Biology and Ecology. 2004;313:47-62.

22. Suzuki M, Wakana I, Denboh T, Tatewaki M. An allelopathic polyunsaturated fatty acid from red algae. Phytochemistry. 1996;43(1):63-65.

23. Suzuki $Y$, Takabayashi $T$, Kawaguchi T, Matsunaga K. Isolation of an allelopathic substance from the crustose coralline algae, Lithophyllum spp., and its effect on the brown alga, Laminaria religiosa Miyabe (Phaeophyta). Journal of Chemical Ecology. 1998;225(1):69-77.

24. Gross E. Allelopathy of aquatic autotrophs. In: Critical Reviews in Plant Science. 2003;22(3-4):313-339.

25. Faulkner DJ. Marine natural products. Natural Products Report. 1997;14:259301.

26. Hay ME, Fenical W. Marine plantherbivores interactions: The ecology of chemical defense. Annual Review of Ecology and Systematics. 1988;19:111145.

27. Dicky G, Davis J, Vasanthi AHR. Seaweed metabolite database (SWMD): A database of natural compounds from marine algae. Bioinformation. 2011;5(8):361-364.

28. Hay ME. The role of seaweed chemical defenses in the evolution of feeding specialization and in the mediation of complex interactions. In: Paul, VJ (Ed) Ecological Roles of Marine Natural Products. Cornell University Press, Ithaca and London. 1992;93-118.

29. Hay ME, Steinberg PD. The chemical ecology of plant-herbivore interactions in marine versus terrestrial communities. In: Rosenthal $\mathrm{J} \& \mathrm{M}$ Berenbaum (Eds) Herbivores: Their Interaction with Secondary Plant Metabolites. Evolutionary and Ecological Processes. Academic Press, New York. 1992;2:371-413.

30. Schmitt TM, Hay ME, Lindquist $N$. Constraints on chemically mediated coevolution: Multiple functions of seaweed secondary metabolites. Ecology. 1995;76: 107-123.

31. Demko AM, Amsler CD, Hay ME, Long JD, McClintock JB, Paul VJ, Sotka EE. Declines in plant palatability from polar to tropical latitudes depend on herbivore and plant identity. Ecology. 2017;98(9):23122321.

32. Faulkner DJ. Marine natural products: Metabolites of marine algae and herbivorous marine mollusks. Natural Products Report. 1984;1:251-280.

33. Fenical W. Halogenation in the Rhodophyta: A review. Journal of Phycology. 1975;11:245-259.

34. Retz de Carvalho L, Roque NF. Correlations between primary and secondary metabolites in Ceramiales (Rhodophyta). Biochemical Systematics and Ecology. 2004;32(3):337-342.

35. Paul VJ, Fenical W. Isolation of halimedatrial: Chemical defense adaptation in the calcareous reef-building alga Halimeda. Science. 1983;221:747749.

36. Paul VJ, Fenical W. Chemical defense in tropical green algae, Order Caulerpales. Marine Ecology Progress Series. 1986;34: 157-169.

37. Paul VJ, van Alstyne KL. Chemical defenses and chemical variation in some tropical Pacific species of Halimeda (Halimedaceae; Chlorophyta). Coral Reefs. 1988;6:263-269.

38. El Gamal AA. Biological importance of marine algae. Saudi Pharmaceutical Journal. 2010;18(1):1-25.

39. Carvalho LRS, Barros F. Physical habitat structures in marine ecosystems: The meaning of complexity and heterogeneity. Hydrobiologia. 2017;797:1-9.

40. Kovalenko KE, Thomaz SM, Warfe DM. Habitat complexity: Approaches and future directions. Hydrobiologia. 2012;685:1-17.

41. McCoy ED, Bell SS. Habitat structure: The evolution and diversification of a complex topic. In: Bell SS, McCoy ED \& Mushinsky HR, (Eds), Habitat Structure: The physical arrangement of objects in space. Chapman and Hall, London. 1991;3-27.

42. Tews J, Brose U, Grimm V, Tielborger K, Wichmann MC, Schwager M, Jeltsch F. Animal species diversity driven by habitat heterogeneity/diversity: The importance of keystone structures. Journal of Biogeography. 2004;31:79-92.

43. Tokeshi M, Arakaki S. Habitat complexity in aquatic systems: Fractals and beyond. Hydrobiologia. 2011;685:27-47.

44. Wiens JA. Ecological heterogeneity: An ontogeny of concepts and approaches. In: Hutchings MJ, EA John \& AJA Stewart, (Eds). The Ecological Consquences of 
Environmental Hewterogeneity. Blackwell Science, Oxford. 2000;9-31.

45. Paul VJ. Seaweed chemical defense on coral reefs. p. 24-50. In: Paul VJ (Ed) Ecological Roles of Marine Natural Products. Comstock Publication Association, USA. 1992;245.

46. Eynaud Y, McNamara DE, Sandin SA. Herbivore space use influences coral reef recovery. Royal Society Open Science. 2016;3(6):160262.

47. González-González J, Gold M, León $H$, Candelaria C, León D, Serviere E, Fragoso D. Catálogo onomástico (nomenclator) y bibliográfico indexado de las algas bentónicas marinas de México. Cuaderno 29. Instituto de Biología. UNAM. México. 1994;494.

48. De Lara-Isassi G, Álvarez-Hernández S, Collado-Vides L. Ichthyotoxic activity of extracts from Mexican marine macroalgae. Journal of Applied Phycology. 2000;12. Sreenivasa-Rao PR, Parekh KS. Antibacterial activity of Indian seaweed extracts. Botanica Marina. 1981;24:577582.

49. Lopes RV, Fernández $\mathrm{N}$, Martins RF, Vasconcelos V. Primary screening of the bioactivity of brackishwater Cyanobacteria: Toxicity of crude extracts to Artemia salina Larvae and Paracentrotus lividus Embryos. Marine Drugs. 2010;8(3):471-482.

50. Rodríguez-Palacio MC, CrisóstomoVázquez L, Álvarez-Hernández S, LozanoRamírez C. Strains of toxic and harmful microalgae, from wastewater, marine, brackish and freshwater. Food Additives \&
Contaminants: Part A. 2011;29(2):304313.

51. Green G. Ecology of toxicity in marine sponges. Marine Biology. 1977;40:207215.

52. Hammer $\varnothing$, Harper DAT, Ryan PD. PAST: Paleontological Statistics Software Package for education and data analysis. Palaeontologia Electronica. 2001;4(1):9.

53. Hay ME. Predictable spatial scapes from herbivory: How do these affect the evolution of herbivore resistance in tropical marine communities? Oecology. 1984;64: 396-407.

54. Matlock DB, Ginsburg DW, Paul VJ. Spatial variability in secondary metabolite production by the tropical red alga Portieria hornemannii. Hydrobiologia. 1999;398/399: 267-273.

55. Hay ME, Paul VJ, Lewis SM, Gustafson K, Tucker J, Trindell RN. Does the tropical seaweed Halimeda reduce herbivory by growing at night? Diel patterns of growth, nitrogen content, herbivory, and chemical versus morphological defenses. Oecologia. 1988;81:418-427.

56. Paul VJ, Littler MM, Littler DS, Fenical W. Evidence for chemical defense in tropical green algae Caulerpa ashmeadii (Caulerpaceae: Chlorophyta): Isolation of a new bioactive sesquiterpenoid. Journal of Chemical Ecology. 1987;13:1171-1185.

57. Nagarajan S, Mathaiyan M. Emerging novel anti HIV biomolecules from marine algae: An overview. Journal of Applied Pharmaceutical Science. 2015;5(09):153158.

(c) 2019 Alvarez-Hernández et al.; This is an Open Access article distributed under the terms of the Creative Commons Attribution License (http://creativecommons.org/licenses/by/4.0), which permits unrestricted use, distribution, and reproduction in any medium, provided the original work is properly cited.

Peer-review history:

The peer review history for this paper can be accessed here: http://www.sdiarticle3.com/review-history/50349 